\title{
Keragaman dan Potensi Genetik Ubi Jalar Lokal Pada Kondisi Partial Submergence
}

\author{
Genetic Diversity and Potentials of Local Sweet Potato under Partial Submergence Condition
}

\section{Helen Hetharie ${ }^{1, *}$, Simon H.T. Raharjo ${ }^{1}$, Anna Y. Wattimena ${ }^{1}$, Reny Tomasoa ${ }^{1}$, dan La Dahamarudin ${ }^{2}$}

\author{
${ }^{1}$ Jurusan Budidaya Pertanian Fakultas Pertanian Universitas Pattimura, Jl. Ir. M. Putuhena Kampus Poka Ambon \\ 97233, Indonesia \\ ${ }^{2}$ Balai Pengkajian Teknologi Pertanian Maluku, Jl. Soplanit, Rumahtiga, Ambon 97234 \\ *Penulis Korespondensi: e-mail: helen_hetharie@yahoo.com
}

\begin{abstract}
Excess ground water above normal due to high rainfall affect the growth and yields of crops. The objectives of the study were to measure the genetic diversity of local sweet potato clones, to obtain characters of vegetative and yield characters that were responsive against of partial submergence and sweet potato clones that had highest yield components. The method of research was a one-factor experiment involving 21 sweet potato clones using a Completely Randomized Block design with 3 replication. The partial submergence in this study mean that was the lower parts of the plants submerged when the plant were 2 and 3 months old. Data were analyzed with $F$ test, genotype and phenotype variance, and DMRT test. The results show the sweet potato clones have a wide diversities of vegetative and yield characters. Vegetative characters that were positively responsive to partial submergence were the number of green leaves, leaf area per plant, leaf area index, and stem length. Yield characters that were positively responsive to partial submergence were tuber number and tuber length. Some of the clones with the highest production potential were shown through two of the three yields indicators (tubers number, individual tuber weight and tuber weight per plant), i.e. Al3, AR15, B9, BSepa-U, BR5, H1 clones and Antin 2 variety..
\end{abstract}

Keywords: excess water, genotype variance, Ipomoea batatas, Maluku, yield character

\section{ABSTRAK}

Kelebihan air tanah di atas normal akibat curah hujan yang tinggi mempengaruhi pertumbuhan dan produksi tanaman. Tujuan penelitian untuk mengukur keragaman genetik klon-klon ubi jalar lokal, serta mendapatkan karakter vegetatif dan karakter hasil yang responsif positif terhadap partial submergence dan klon ubi jalar yang mempunyai komponen hasil tertinggi. Metode penelitian berupa percobaan satu faktor yaitu 21 klon ubi jalar menggunakan rancangan acak lengkap berblok dengan pengulangan tiga kali. Partial submergence dalam penelitian ini yaitu bagian bawah dari tanaman terendam air pada umur tanaman 2 dan 3 bulan. Analisis data dengan uji F, ragam genotip dan fenotip, dan uji DMRT. Hasil menunjukkan bahwa klon-klon ubi jalar mempunyai keragaman luas pada semua karakter vegetatif dan produksi. Karakter vegetatif yang responsif positif terhadap partial submergence yaitu jumlah daun hijau, luas daun per tanaman, indeks luas daun dan panjang batang. Karakter produksi yang responsif positif terhadap partial submergence yaitu jumlah umbi dan panjang umbi. Beberapa klon dengan potensi produksi melalui dua dari tiga indikator produksi (jumlah umbi, bobot per umbi dan bobot umbi segar per tanaman) tertinggi yaitu A13, A15, B9, BSepa-U, BR5, H1, dan varietas Antin 2.

Kata kunci: Ipomoea batatas, karakter hasil, Maluku, ragam genotip, terendam

\section{PENDAHULUAN}

Ubi jalar (Ipomoea Batatas L. Lam) merupakan salah satu tanaman umbi-umbian sumber karbohidrat utama di Maluku. Selain itu, tanaman ini merupakan tanaman pangan sumber karbohidrat setelah padi, jagung dan ubi kayu di Indonesia. Selain sebagai sumber karbohidrat, ubi jalar merupakan sumber vitamin, $\beta$ karoten dan antioksidan penting bagi kesehatan masyarakat terutama yang berdaging umbi berwarna ungu dan oranye.

Sumber daya genetik ini mempunyai keragaman fenotipik yang cukup tinggi berdasarkan morfologi daun, batang maupun umbi. Di provinsi Maluku, komoditas ini ditemukan juga mempunyai keragaman tinggi pada tingkat insitu (Raharjo et al., 2014), maupun pada tingkat eksitu (Hetharie et al., 2017). Keragaman yang tinggi dikendalikan secara genetik atau merupakan interaksi faktor genetik dengan lingkungan tumbuh. Ubi jalar 
termasuk tanaman heksaploid dengan jumlah kromosom yang cukup banyak $(2 \mathrm{n}=6 \mathrm{x}=90)$, tidak kesesuaian sendiri, dan menyerbuk silang (Ozias-Akins dan Jarret, 1994). Keragaman genetik dalam koleksi menjadi penting karena plasma nutfah itu dapat digunakan sebagai sumber gen untuk perbaikan sesuai tujuan pemuliaan.

Perubahan iklim global saat ini berdampak pada perubahan curah hujan yang mengakibatkan kelebihan air pada lahan-lahan pertanian di atas kejadian normal. Tanaman-tanaman yang tercekam kelebihan air akan memperlihatkan penurunan pertumbuhan dan berdampak terhadap organ-organ reproduksi. Kejadian cekaman air pada tanaman dikelompokkan atas: 1) waterlogging menggambarkan sistem akar saja yang terendam; dan 2) submergence atau flooding. Ketika sebagian tanaman terendam air diistilahkan dengan partial submergence dan jika seluruh tanaman terendam disebut all submergence (Striker, 2010; Bailey-Serres et al., 2012). Waterlogging berdampak negatif terhadap cape gooseberry yang diperlihatkan melalui reduksi luas daun, penutupan stomata, layu daun, yang berdampak pada menurunnya jumlah kuncup bunga, jumlah bunga dan jumlah buah (Aldana et al., 2014). Ezin et al. (2010) menemukan bahwa penurunan jumlah bunga dan buah, serta ukuran dan berat buah pada tomat diakibatkan oleh penghambatan fotosintesis pada kondisi flooding. Scott et al. (1989) mendapatkan bahwa tanaman kedele pada kondisi flooding selama dua hari diakhir dari partumbuhan vegetatif menyebabkan kehilangan hasil $18 \%$, dan pada tahap awal reproduksi terjadi kehilangan hasil $26 \%$.

Penggunaan varietas yang toleran terhadap cekaman kelebihan air tanah diperlukan saat ini untuk mengantisipasi perubahan cuaca serta memanfaatkan lahan tidak produktif karena terendam air ketika musim hujan. Ubi jalar merupakan salah satu tanaman yang tidak toleran terhadap kondisi waterlogging, terutama pada inisiasi umbi (Wilson, 1982). Perbaikan ubi jalar toleran terhadap kelebihan air pada kondisi waterlogging maupun submergence dapat dilakukan jika tersedia sumber gen dalam koleksi. Penjaringan klon-klon ubi jalar yang mampu bertumbuh dan berproduksi pada kondisi partial submergence diperlukan untuk menjawab kebutuhan sumber gen tersebut. Dengan demikian tujuan penelitian ini adalah mengukur keragaman genetik klon-klon ubi jalar berdasarkan ragam genetik dan ragam fenotip, mendapatkan karakter vegetatif dan komponen produksi yang responsif terhadap partial submergence, mendapatkan klon ubi jalar yang mempunyai komponen hasil tertinggi.

\section{BAHAN DAN METODE}

Penelitian berlangsung di Desa Rumah Tiga, kota Ambon, terhadap 21 klon ubi jalar terdiri dari 19 klon lokal yang berasal dari Kabupaten Seram Bagian Barat, Maluku Tengah, Buru Selatan, Maluku Tenggara, Maluku Tenggara Barat, dan Kota Ambon, dan 2 varietas unggul yaitu Antin 2 dan Cilembu dari Balai Penelitian Kacang dan Umbi-Umbian, Malang. Percobaan adalah percobaan faktor tunggal yaitu 21 klon ubi jalar sebagai perlakuan menggunakan Rancangan Acak Lengkap Berblok dengan pengulangan tiga kali. Ubi jalar ditanam dengan menggunakan stek pucuk. Penanaman dengan jarak tanam $75 \times 40 \mathrm{~cm}$. Petak berukuran $275 \times 170 \mathrm{~cm}$ yang ditanam dengan 16 tanaman, terdiri dari 4 tanaman ubinan dan 12 tanaman samping. Pemberian pupuk kandang $300 \mathrm{~g}$ per lubang tanam sebelum tanam, $9 \mathrm{~g}$ NPK per tanaman umur 2 minggu setelah tanam, dan masing-masing $3 \mathrm{~g}$ Urea dan $\mathrm{KCl}$ per tanaman pada umur tanaman 2 bulan.

Penanaman dilakukan pada bulan April dan panen bulan September 2017. Pada masa tersebut curah hujan tertinggi terutama pada bulan Mei, Juni dan Juli (Tabel 1). Pada kondisi ini, permukaan petak dan bagian-bagian tanaman yang dekat permukaan tanah terendam air yaitu pada umur tanaman 2 dan 3 bulan setelah tanam. Selanjutnya air mulai berkurang sejalan dengan berkurangnya curah hujan.

Pengamatan karakter vegetatif terhadap 4 tanaman samping pada umur tanaman 4 bulan meliputi jumlah daun hijau, luas daun per tanaman $\left(\mathrm{cm}^{2}\right)$, indeks luas daun, panjang batang $(\mathrm{cm})$, rata-rata panjang ruas batang $(\mathrm{cm})$, dan jumlah cabang primer. Pengamatan komponen hasil terhadap 4 tanaman ubinan meliputi jumlah umbi per tanaman, rata-rata panjang umbi $(\mathrm{cm})$, rata-rata diameter umbi $(\mathrm{cm})$, rata-rata bobot per umbi $(\mathrm{g})$, dan bobot umbi segar per tanaman atau hasil (g). Khusus data komponen hasil dan hasil sebelum dilakukan uji ragam, data ditransformasi dengan square root (SQRT data +0.5 ).

Analisis data meliputi analisia ragam dengan uji $\mathrm{F}$ $\alpha=5 \%$ dan $\alpha=1 \%$, karakter yang menunjukkan pengaruh nyata dan sangat nyata dilanjutkan dengan uji beda Duncan. Analisis ragam dan uji beda menggunakan program SAS dan program exel. Pendugaan ragam genotip dan ragam fenotip dan membandingkannya dengan standar deviasi ragam genotip $\left(\sigma_{\sigma_{g}^{2}}\right)$ dan fenotip $\left(\sigma_{\sigma_{p}^{2}}\right.$ ) seperti yang digunakan oleh Syukur et al. (2010) dan Putri et al. (2017).

Tabel 1. Data klimatologi selama penelitian

\begin{tabular}{lcccc}
\hline Bulan & Suhu Rata-Rata $\left({ }^{\circ} \mathrm{C}\right)$ & Curah Hujan $(\mathrm{mm})$ & Hari Hujan & Penyinaran Matahari $(\%)$ \\
\hline Maret & 27 & 143 & 23 & 57 \\
April & 26.9 & 129 & 26 & 65 \\
Mei & 26.4 & 753 & 29 & 40 \\
Juni & 25.4 & 1430 & 29 & 2 \\
Juli & 25.4 & 1046 & 27 & 32 \\
Agustus & 25.6 & 452 & 29 & 28 \\
September & 26.0 & 501 & 25 & 33 \\
\hline
\end{tabular}

Sumber: Badan Meteorologi Klimatologi dan Geofisika. Stasiun Meteorologi Pattimura Ambon Tahun 2017 


$$
\begin{aligned}
\sigma_{g}{ }^{2} & =\frac{K T_{g}-K T_{\text {galat }}}{r} \quad \sigma_{p}^{2}=\sigma_{g}{ }^{2}+\sigma_{e}^{2} \\
K T_{\text {galat }} & =\sigma_{e}^{2} \\
\sigma_{\sigma_{g}^{2}} & =\sqrt{\frac{2}{r^{2}}\left\{\frac{K T_{g}^{2}}{d b_{g}+2}+\frac{K T_{e}^{2}}{d b_{e}+2}\right\}} \\
\sigma_{\sigma_{p}^{2}} & =\sqrt{\frac{2}{r^{2}}\left\{\frac{K T_{g}{ }^{2}}{d b_{g}+2}\right\}}
\end{aligned}
$$

Keterangan: $\mathrm{KTg}=$ kuadrat tengah genotip, $\mathrm{KTe}=$ kuadrat tengah galat, $\mathrm{r}=$ ulangan, ${\sigma_{g}}^{2}=$ ragam genotip, $\sigma_{p}{ }^{2}=$ ragam fenotip, $\sigma_{e}{ }^{2}=$ ragam lingkungan, $\mathrm{db}_{\mathrm{g}}=$ derajat bebas genotip, $\mathrm{db}_{\mathrm{e}}=$ derajat bebas galat.

\section{HASIL DAN PEMBAHASAN}

\section{Keragaman Genetik Berdasarkan Karakter Vegetatif dan Karakter Produksi}

Keragaman genetik klon-klon ubi jalar dapat diukur salah satunya dengan menduga ragam genetik dan fenotip. Kategori keragaman genotip luas apabila ragam genotip $\left(\sigma_{\mathrm{g}}{ }^{2}\right)$ lebih besar dari dua kali standar deviasi ragam genotip $\left(2 \times \sigma \sigma_{\mathrm{g}}{ }^{2}\right.$ ), dan keragaman sempit apabila ragam genotip lebih kecil dari dua kali standar deviasi ragam genotip (Pinaria et al., 1995). Semua karakter vegetatif dan karakter produksi menunjukkan keragaman genotip pada kategori luas (Tabel 2). Ini mengindikasikan bahwa klon-klon ubi jalar yang diteliti berasal dari latarbelakang genetik yang berbeda. Menurut Qosim et al. (2013), jika populasi berasal dari tetua dengan latarbelakang genetik yang berbeda maka keragaman genetik dalam populasi tersebut lebih besar jika dibandingkan dengan populasi tetua yang dekat jarak genetik. Menurut Badu et al. (2017), pendugaan parameter genetik merupakan dasar dalam program seleksi dan persilangan untuk perbaikan karakter berdasarkan keragaman. Klon-klon ubi jalar yang diteliti dapat sebagai sumber gen untuk perbaikan karakter toleran cekaman terendam air, sekaligus dapat diperoleh variasi-variasi baru melalui persilangan.

Keragaman luas juga diperlihatkan pada klon-klon ubi jalar melalui fenotip pada semua karakter vegetatif maupun karakter produksi (Tabel 2). Kategori keragaman fenotip luas apabila ragam fenotip $\left(\sigma_{\mathrm{p}}{ }^{2}\right)$ lebih besar dari dua kali standar deviasi ragam fenotip $\left(2 \times \sigma \sigma_{\mathrm{p}}^{2}\right)$, dan keragaman sempit apabila terjadi sebaliknya.

Fenotip suatu karakter dapat dikendalikan oleh faktor genetik, faktor lingkungan ataupun interaksi antar faktor genetik dan lingkungan. Klon-klon ubi jalar yang diteliti mempunyai keragaman yang luas secara genetik maupun fenotip. Keragaman genotip yang luas menjadi pilihan dibandingkan keragaman fenotip yang luas. Namun demikian keragaman fenotip dapat digunakan untuk mempermudah membedakan secara visual klonklon ubi jalar dalam populasi terutama jika keragaman genotip dan fenotip sama-sama pada kategori luas. Wahyuni et al. (2004) juga mendapatkan keragaman luas secara genotip maupun fenotip pada 9 dari 10 karakter pada 45 klon klon ubi jalar yang diuji, kecuali panjang umbi.

\section{Keragaan Karakter Vegetatif Klon-Klon Ubi Jalar Setelah Partial Submergence}

Klon-klon ubi jalar yang diuji mempunyai akar dan bagian tanaman dekat tanah terendam pada umur tanaman 2 dan 3 bulan setelah tanam namun mampu bertumbuh

\begin{tabular}{|c|c|c|c|c|c|c|c|}
\hline $\begin{array}{l}\text { Karakter } \\
\text { Vegetatif }\end{array}$ & $\begin{array}{l}2 \mathrm{x} \sigma \sigma_{\mathrm{g}}{ }^{2} \\
2 \mathrm{x} \sigma \sigma_{\mathrm{p}}{ }^{2}\end{array}$ & $\begin{array}{l}\sigma_{g}^{2} \\
\sigma_{p}^{2}\end{array}$ & Kriteria & $\begin{array}{l}\text { Karakter } \\
\text { Produksi }\end{array}$ & $\begin{array}{l}2 \times \sigma \sigma_{\mathrm{g}}{ }^{2} \\
2 \times \sigma \sigma_{\mathrm{p}}{ }^{2}\end{array}$ & $\begin{array}{l}\sigma_{\mathrm{g}}{ }^{2} \\
\sigma_{\mathrm{p}}{ }^{2}\end{array}$ & Kriteria \\
\hline \multirow{2}{*}{$\mathrm{JDH}$} & 873.49 & 1256.85 & Luas & $\mathrm{JU}$ & 0.21 & 0.30 & Luas \\
\hline & 869.74 & 1813.18 & Luas & & 0.21 & 0.45 & Luas \\
\hline \multirow[t]{2}{*}{ LDT } & 2042870.33 & 2373797.25 & Luas & PU & 0.07 & 0.08 & Luas \\
\hline & 2000870.22 & 5206609.15 & Luas & & 0.07 & 0.19 & Luas \\
\hline \multirow[t]{2}{*}{ ILD } & 0.23 & 0.26 & Luas & DU & 0.02 & 0.02 & Luas \\
\hline & 0.22 & 0.58 & Luas & & 0.02 & 0.06 & Luas \\
\hline \multirow[t]{2}{*}{ PB } & 6406.75 & 9756.94 & Luas & BU & 0.68 & 0.76 & Luas \\
\hline & 6396.01 & 12035.87 & Luas & & 0.66 & 1.77 & Luas \\
\hline \multirow[t]{2}{*}{ PRsB } & 0.49 & 0.74 & Luas & HUT & 5.46 & 6.44 & Luas \\
\hline & 0.48 & 0.93 & Luas & & 5.36 & 13.75 & Luas \\
\hline \multirow[t]{2}{*}{$\mathrm{JC}$} & 0.68 & 0.77 & Luas & & & & \\
\hline & 0.66 & 1.75 & Luas & & & & \\
\hline
\end{tabular}
dan berproduksi sesuai kemampuan genetik masingmasing klon.

Tabel 2. Ragam genetik dan fenotip pada beberapa karakter vegetatif dan karakter produksi

Keterangan: $\sigma_{\mathrm{g}}^{2}=$ ragam genotip, $\sigma_{\mathrm{p}}^{2}=$ ragam fenotip; $2 \mathrm{x} \sigma \sigma_{\mathrm{g}}^{2}=$ dua kali standar deviasi ragam genotip; $2 \mathrm{x} \sigma \sigma_{\mathrm{p}}^{2}=$ dua kali standar deviasi ragam fenotip, JDH=jumlah daun hijau per tanaman, LID=luas individu daun, LDT=luas daun per tanaman, ILD=indeks luas daun, $\mathrm{PB}=$ panjang batang, $\mathrm{PRsB}=$ panjang ruas batang, $\mathrm{JC}=$ jumlah cabang, $\mathrm{JU}=$ jumlah umbi, $\mathrm{PU}=$ panjang umbi, $\mathrm{DU}=$ diameter umbi, BU=bobot per umbi, HUT=hasil per tanaman 
Hasil uji $\mathrm{F}$ menunjukkan perbedaan sangat nyata pada semua karakter vegetatif dan komponen hasil. Hasil uji beda berganda Duncan untuk beberapa karakter vegetatif seperti pada Tabel 3. Klon-klon ubi jalar yang menunjukkan jumlah daun hijau terbanyak setelah mengalami partial submergence yaitu klon B33 dan varietas Cilembu. Luas daun per tanaman tertinggi diperlihatkan oleh klon BR5, B5, B39, B33, B65, AR1 dan B70, serta indeks luas daun tertinggi pada klon B5, BR5, B39, B33, AR1, B65 dan B70. Hasil ini menunjukkan bahwa pada kondisi partial submergence sebagian besar klon memperlihatkan kemampuan genetik untuk menghasilkan organ hijauan yang lebih tinggi. Sedangkan enam klon ubi jalar lokal yaitu A13, A15, AHT-U, B43, H1, LR2, termasuk varietas Antin 2 menunjukkan keragaan dari ketiga karakter vegetatif tersebut lebih rendah (Tabel 3). Jumlah daun hijau yang banyak dan luas daun per tanaman yang besar pada cekaman air merupakan bentuk toleransi positif klon-klon ubi jalar untuk keberlangsung fotosintesis. Hossain dan Uddin (2011) menyatakan gandum menunjukkan toleran terhadap genangan air tergantung dari kemampuannya merubah sifat-sifat morfologi dan metabolik terhadap cekaman untuk mampu hidup dan bertumbuh. Ezin et al. (2010) mendapatkan salah satu genotip tomat memberikan respons negatif pada kondisi waterlogging dengan $80 \%$ daun berwarna kuning dibandingkan kontrol. Respons negatif pada cape goosberry yaitu 75-100\% daun menggulung terutama 8 hari pada kondisi waterlogging (Aldana et al., 2014).
Klon-klon yang mencirikan batang yang terpanjang yaitu klon B43 dan B65, diikuti dengan klon B5, A13, LR2 dan A15 pada selang 329-570 cm (Tabe 3). Umumnya klon-klon yang mempunyai batang yang panjang menunjukkan juga ruas batang yang panjang kecuali klon A15, sedangkan varietas antin 2 menunjukkan batang yang relatif pendek namun ruas antar batangnya panjang.

Beberapa penelitian menunjukkan panjang batang ubi jalar pada lingkungan optimal yaitu pada selang 48$246 \mathrm{~cm}$ yang diamati pada 45 klon (Wahyuni et al., 2004), dan pada 62 genotipe ubi jalar pada selang 83.0-283.80 cm (Rahajeng dan Rahayuningsih, 2017). Batang yang sangat panjang mencapai $400-500 \mathrm{~cm}$ pada beberapa klon ubi jalar dalam penelitian ini diduga berkaitan dengan respons tanaman pada kondisi partial submergence. Suatu respons pemanjangan bagian-bagian tanaman untuk berada di atas air. Kende et al. (1998) mendapatkan terjadi pemanjangan pada ruas batang berdampak pada pemanjangan batang tanaman padi pada kondisi tanaman terendam.

Hasil penelitian juga mendapatkan delapan klon ubi jalar lokal mempunyai jumlah cabang terbanyak termasuk varietas Cilembu, namun dua klon diantaranya yang mempunyai jumlah cabang yang banyak diikuti dengan jumlah daun banyak yaitu klon B33 dan varietas Cilembu. Karakter-karakter vegetatif ini menjadi penting berkaitan dengan kemampuan klon-klon ubi jalar untuk bertumbuh pada kondisi partial submergence terutama untuk keberlangsungan fotosintesis.

Tabel 3. Hasil uji beda Duncan beberapa karakter vegetatif klon-klon ubi jalar pada partial submergence

\begin{tabular}{lrrrrrr}
\hline \multicolumn{1}{c}{$\begin{array}{c}\text { Nama } \\
\text { Klon }\end{array}$} & $\begin{array}{r}\text { Jumlah } \\
\text { daun hijau }\end{array}$ & $\begin{array}{r}\text { Luas daun per } \\
\text { tanaman }\left(\mathrm{cm}^{2}\right)\end{array}$ & $\begin{array}{c}\text { Indeks luas } \\
\text { daun }\end{array}$ & $\begin{array}{c}\text { Panjang } \\
\text { batang }(\mathrm{cm})\end{array}$ & $\begin{array}{r}\text { Panjang rs } \\
\text { batang }(\mathrm{cm})\end{array}$ & $\begin{array}{c}\text { Jumlah cabang } \\
\text { primer }\end{array}$ \\
\hline AR1 & $130,50 \mathrm{def}$ & $8398.70 \mathrm{abcd}$ & $2,80 \mathrm{abcd}$ & $275,50 \mathrm{de}$ & $3,59 \mathrm{ghij}$ & $7,50 \mathrm{a}$ \\
A13 & $108,67 \mathrm{ef}$ & $6342.97 \mathrm{bcde}$ & $2,11 \mathrm{bcdef}$ & $385,00 \mathrm{bc}$ & $6,10 \mathrm{a}$ & $5,83 \mathrm{abc}$ \\
A15 & $107,33 \mathrm{ef}$ & $5758.44 \mathrm{bcdef}$ & $1,92 \mathrm{bcdef}$ & $312,50 \mathrm{bcd}$ & $3,67 \mathrm{fghij}$ & $5,83 \mathrm{abc}$ \\
AHT-U & $123,00 \mathrm{def}$ & $6236.71 \mathrm{bcdef}$ & $2,08 \mathrm{bcdef}$ & $273,33 \mathrm{de}$ & $4,49 \mathrm{cdef}$ & $5,33 \mathrm{bc}$ \\
B5 & $159,33 \mathrm{bcd}$ & $10467.06 \mathrm{a}$ & $3,49 \mathrm{a}$ & $400,67 \mathrm{~b}$ & $5,85 \mathrm{a}$ & $5,00 \mathrm{c}$ \\
B9 & $91,33 \mathrm{f}$ & $6681.24 \mathrm{bcde}$ & $2,23 \mathrm{bcde}$ & $231,33 \mathrm{def}$ & $3,89 \mathrm{efghi}$ & $7,00 \mathrm{ab}$ \\
B33 & $229,67 \mathrm{a}$ & $8585.38 \mathrm{abc}$ & $2,86 \mathrm{abc}$ & $212,83 \mathrm{efg}$ & $3,42 \mathrm{hij}$ & $7,67 \mathrm{a}$ \\
B39 & $94,33 \mathrm{f}$ & $8696.23 \mathrm{ab}$ & $2,90 \mathrm{ab}$ & $298,83 \mathrm{cde}$ & $3,95 \mathrm{efgh}$ & $4,50 \mathrm{c}$ \\
B43 & $95,67 \mathrm{ef}$ & $5300.07 \mathrm{cdef}$ & $1,77 \mathrm{cdef}$ & $570,33 \mathrm{a}$ & $5,75 \mathrm{ab}$ & $4,33 \mathrm{c}$ \\
B65 & $141,00 \mathrm{cde}$ & $7940.15 \mathrm{abcd}$ & $2,65 \mathrm{abcd}$ & $502,67 \mathrm{a}$ & $4,95 \mathrm{bc}$ & $4,67 \mathrm{c}$ \\
B70 & $122,00 \mathrm{def}$ & $7641.47 \mathrm{abcde}$ & $2,54 \mathrm{abcde}$ & $148,83 \mathrm{fg}$ & $3,09 \mathrm{ij}$ & $7.00 \mathrm{ab}$ \\
B82 & $94,00 \mathrm{f}$ & $6125.84 \mathrm{bcdef}$ & $2,04 \mathrm{bcdef}$ & $288,00 \mathrm{cde}$ & $3,93 \mathrm{efgh}$ & $5,17 \mathrm{bc}$ \\
B102 & $127,00 \mathrm{def}$ & $6960.51 \mathrm{bcde}$ & $2,32 \mathrm{bcde}$ & $302,67 \mathrm{cde}$ & $4,67 \mathrm{cde}$ & $5,00 \mathrm{c}$ \\
BSepa-U & $180,33 \mathrm{bc}$ & $5503.62 \mathrm{bcdef}$ & $1,84 \mathrm{bcdef}$ & $137,33 \mathrm{~g}$ & $2,92 \mathrm{j}$ & $7,00 \mathrm{ab}$ \\
BR5 & $164,33 \mathrm{bcd}$ & $10250.71 \mathrm{a}$ & $3,42 \mathrm{a}$ & $296,67 \mathrm{cde}$ & $3,95 \mathrm{efgh}$ & $4,33 \mathrm{c}$ \\
H1 & $126,33 \mathrm{def}$ & $6182.83 \mathrm{bcdef}$ & $2,06 \mathrm{bcdef}$ & $293,83 \mathrm{cde}$ & $4,13 \mathrm{defgh}$ & $5,17 \mathrm{bc}$ \\
LR2 & $106,00 \mathrm{ef}$ & $5221.60 \mathrm{def}$ & $1,74 \mathrm{def}$ & $329,00 \mathrm{bcd}$ & $4,80 \mathrm{bcd}$ & $4,83 \mathrm{c}$ \\
TL1 & $90,00 \mathrm{f}$ & $6411.00 \mathrm{bcde}$ & $2,14 \mathrm{bcde}$ & $307,83 \mathrm{cde}$ & $4,26 \mathrm{cdefg}$ & $5,83 \mathrm{abc}$ \\
TL8 & $90,67 \mathrm{f}$ & $5911.17 \mathrm{bcdef}$ & $1,97 \mathrm{bcdef}$ & $281,50 \mathrm{de}$ & $3,86 \mathrm{efghi}$ & $4,83 \mathrm{c}$ \\
Antin2 & $112,33 \mathrm{ef}$ & $4397.81 \mathrm{ef}$ & $1,47 \mathrm{ef}$ & $293,17 \mathrm{cde}$ & $4,94 \mathrm{bc}$ & $5,33 \mathrm{bc}$ \\
Cilembu & $192,67 \mathrm{ab}$ & $3049.61 \mathrm{f}$ & $1,02 \mathrm{f}$ & $173,33 \mathrm{fg}$ & $2,96 \mathrm{j}$ & $6,17 \mathrm{abc}$ \\
\hline KK & $18,44 \%$ & $24.88 \%$ & $24,91 \%$ & $16,79 \%$ & $11,00 \%$ & $17,59 \%$ \\
\hline KK & & &
\end{tabular}

Keterangan: angka-angka yang ditandai dengan huruf yang sama pada kolom yang sama tidak berbeda nyata menggunakan uji beda Duncan. KK= koefisien keragaman. 
Tanaman yang toleran mempunyai kandungan klorofil daun yang tinggi (Malik et al., 2015), tanaman lebih tinggi karena terjadi pemanjangan organ-organ tanaman yang berada di atas air (Striker et al., 2012), termasuk pemanjangan tangkai daun (Chen et al., 2010), terbentuk banyak akar adventif yang mempunyai aerenkim menggantikan akar-akar tua yang terendam (Ahmed et al., 2013). Menurut Badu et al. (2017) walaupun beberapa karakter ubi jalar seperti panjang batang, indeks luas daun, luas dan berat daun tidak penting bagi konsumen namun menjadi penting bagi pemulia karena karakter-karakter tersebut menyediakan karbohidrat untuk pertumbuhan umbi dalam kaitan dengan produksi.

\section{Potensi Produksi Klon-klon Ubi Jalar pada Partial Submergence}

Hasil uji beda berganda Duncan memperlihatkan keragaman antar klon ubi jlar pada semua karakter komponen hasil menunjukkan kecirian dari tiap-tiap klon setelah kondisi partial submergence. Pada penelitian ini didapatkan jumlah umbi terbanyak pada lima klon ubi jalar yaitu A13, A15, B9, BR5 dan H1 dengan jumlah 1114 umbi per tanaman (Tabel 4). Minantyorini dan Setyowati (2016) mendapatkan ubi jalar pada dataran tinggi menghasilkan jumlah umbi per tanaman 1-4 umbi. Jumlah umbi yang banyak pada klon-klon ubi jalar lokal dalam penelitian ini diduga merupakan perkembangan lanjut dari akar-akar adventif. Beberapa peneliti mendapatkan tanaman yang toleran waterlogging, salah satunya menghasilkan akar-akar adventif (Dawood et al., 2013; Hossain dan Uddin, 2011) pada akar adventif ini terbentuk aerenkim untuk menyalurkan udara yang terhubung ke tunas untuk difusi gas pada kondisi terendam (Colmer dan Voesenek, 2009). Sebagian besar akar adventif pada ubi jalar berpotensi menjadi umbi (Chen et al., 2017; Villordon et al., 2009).

Klon-klon dengan karakteristik umbi terpanjang adalah varietas unggul Antin 2 dan BSepa-U berurut $19.90 \mathrm{~cm}$ dan $15.82 \mathrm{~cm}$, diikuti oleh klon AR1, dan B82 (Tabel 4). Potensi lain yang dimiliki oleh klon-klon ubi jalar setelah menagalami submergence yaitu bobot umbi segar per tanaman tertinggi pada klon lokal BSepa-U dan varietas Antin 2 karena didukung oleh umbi yang panjang, diameter umbi yang besar dan bobot per umbi yang berat. Klon B9 mempunyai bobot umbi segar per tanaman yang tinggi didukung oleh diameter umbi, bobot per umbi dan jumlah umbi. Klon A15 menunjukkan bobot umbi segar yang tinggi didukung oleh hanya jumlah umbi yang banyak. Namun bobot umbi segar per tanaman dan diameter umbi dalam penelitian ini masih rendah secara berurut pada selang 20.50-235.00 g, dan 1.28-3.60 cm (Tabel 4). Demikian juga bobot per umbi hanya pada selang 9-55.8g dan masih jauh dari Standar Nasional Indonesia (SNI) nomor 01.4493.1998 kelas III yaitu 75$100 \mathrm{~g}(\mathrm{BSN}, 1998)$.

Tabel 4. Hasil uji beda Duncan terhadap karakter produksi klon-klon ubi jalar pada partial submergence

\begin{tabular}{|c|c|c|c|c|c|}
\hline $\begin{array}{l}\text { Nama } \\
\text { Klon }\end{array}$ & Jumlah Umbi & $\begin{array}{l}\text { Panjang Umbi } \\
(\mathrm{cm})\end{array}$ & $\begin{array}{l}\text { Diameter Umbi } \\
(\mathrm{cm})\end{array}$ & $\begin{array}{c}\text { Bobot Per Umbi } \\
(\mathrm{g})\end{array}$ & $\begin{array}{c}\text { Bobot Umbi Segar/ } \\
\text { Tanaman }(\mathrm{g})\end{array}$ \\
\hline AR1 & 7,00 bcde & $14,08 \mathrm{bc}$ & $2,67 \mathrm{abcd}$ & $28,17 \mathrm{bc}$ & $168,83 \mathrm{abcd}$ \\
\hline A13 & $14,67 \mathrm{a}$ & $9,13 \mathrm{de}$ & 2,13 abcdef & 14,39 bcde & 167,17 abcde \\
\hline A15 & $11,83 \mathrm{ab}$ & 13,04 bcde & 1,87 cdef & $10,33 \mathrm{de}$ & 111,75 abcde \\
\hline AHT-U & $5,00 \mathrm{def}$ & 10,78 cde & 2,48 abcdef & $25,55 \mathrm{bcd}$ & 89,83 bcdef \\
\hline B5 & 5,67 def & $13,39 \mathrm{bcd}$ & 2,66 abcd & $24,80 \mathrm{bcd}$ & 132,00 abcde \\
\hline B9 & $11,33 \mathrm{abc}$ & $13,29 \mathrm{bcd}$ & $2,91 \mathrm{abc}$ & $31,84 \mathrm{ab}$ & $235,00 \mathrm{a}$ \\
\hline B33 & 7,00 bcde & 12,70 bcde & 2,39 abcdef & 23,75 bcde & 152,50 abcde \\
\hline B39 & $2,17 \mathrm{f}$ & 11,01 bcde & 1,39 ef & $9,00 \mathrm{e}$ & $23,17 \mathrm{fg}$ \\
\hline B43 & 3,33 ef & 10,60 cde & 1,69 cdef & 15,58 bcde & 64,00 efg \\
\hline B65 & 3,17 ef & $13,40 \mathrm{bcd}$ & 2,20 abcdef & $24,43 \mathrm{bcd}$ & 71,17 cdefg \\
\hline B70 & 7,67 abcd & 10,25 cde & $1,52 \mathrm{def}$ & 12.66 cde & 97,67 bcde \\
\hline B82 & 6,00 cdef & $14,65 \mathrm{bc}$ & 2,44 abcdef & 19,55 bcde & 102,22 bcde \\
\hline B102 & 7,33 bcde & 11,87 bcde & 2,17 abcdef & 11,05 cde & 92,17 cdefg \\
\hline BSepa-U & $6,00 \mathrm{def}$ & $15,82 \mathrm{ab}$ & $3,60 \mathrm{a}$ & $32,30 \mathrm{ab}$ & $188,67 \mathrm{abcd}$ \\
\hline BR5 & $12,00 \mathrm{ab}$ & $10,23 \mathrm{cde}$ & 2,55 abcde & $24,19 \mathrm{bcd}$ & $220,67 \mathrm{ab}$ \\
\hline H1 & $11,83 \mathrm{ab}$ & $13,25 \mathrm{bcd}$ & 2,60 abcdef & 16,89 bcde & $186,63 \mathrm{abc}$ \\
\hline LR2 & $4,00 \mathrm{def}$ & 11,58 bcde & 1,76 cdef & 16,87 bcde & 78,17 defg \\
\hline TL1 & $2,67 \mathrm{f}$ & $8,67 \mathrm{e}$ & $1,28 \mathrm{f}$ & $10,10 \mathrm{de}$ & $20,50 \mathrm{fg}$ \\
\hline TL8 & $4,67 \mathrm{def}$ & 9,79 cde & 1,93 bcdef & 15,34 bcde & 67,67 defg \\
\hline Antin 2 & 3,50 ef & $19,90 \mathrm{a}$ & $3,34 \mathrm{ab}$ & $55,88 \mathrm{a}$ & 149,33 abcde \\
\hline Cilembu & 4,50 def & 11,23 bcde & 2,45 abcdef & $23,71 \mathrm{bcd}$ & 96,67 bcde \\
\hline KK & $18,23 \%$ & $9,42 \%$ & $12,47 \%$ & $22,51 \%$ & $26,27 \%$ \\
\hline
\end{tabular}

Keterangan: Data pada tabel adalah data asli sedangkan untuk uji F, uji beda Duncan dan KK menggunakan data hasil transformasi. Angka-angka yang ditandai dengan huruf yang sama pada kolom yang sama tidak berbeda nyata menggunakan uji beda Duncan. KK= koefisien keragaman. 
Meskipun demikian ditemukan klon AR1, B9, Bsepa-U, BR5, LR2, dan varietas unggul Antin 2 mampu menghasilkan bobot per umbi pada kisaran SNI kelas III pada 1-2 tanaman ubinan. Wahyuni et al. (2004) menguji 45 klon ubi jalar pada musim kemarau mendapatkan bobot per umbi pada selang 71-291.7 g, panjang umbi pada selang 11.5-18 cm, dan diameter umbi pada selang 3.34$7.35 \mathrm{~cm}$, demikian juga (Rahajeng dan Rahayuningsih, 2017) mendapatkan panjang umbi dan diameter umbi secara berurut pada selang 5.50-18.15 cm dan 3.30-8.60 $\mathrm{cm}$. Bobot umbi per tanaman dari 28 aksesi yang diuji pada dataran tinggi pada selang 817-2083 g (Minantyorini dan Setyowati, 2016). Beberapa karakter umbi dari penelitian tersebut jauh lebih tinggi dari yang didapatkan dalam penelitian ini sebagai indikasi bahwa tanaman ubi jalar pada kondisi terendam air 2 bulan menjelang panen menghambat pertumbuhan umbi terutama diameter umbi, bobot per umbi, dan bobot umbi segar pertanaman.

\section{KESIMPULAN}

Dua puluh satu klon ubi jalar menunjukkan keragaman genetik yang luas pada semua karakter vegetatif maupun komponen hasil berdasarkan ragam genotip dan ragam fenotip. Karakter vegetatif ubi jalar yang responsif positif terhadap partial submergence yaitu jumlah daun hijau, ukuran daun per tanaman dan indeks luas daun dan panjang batang. Karakter produksi yang responsif positif terhadap partial submergence yaitu jumlah umbi dan panjang umbi. Klon ubi jalar A13, A15, B9, BSepa-U, BR5, H1, dan varietas Antin 2 mempunyai potensi produksi tertinggi melalui dua dari tiga indikator produksi yaitu jumlah umbi, bobot per umbi dan bobot umbi segar per tanaman pada kondisi partial submergence.

\section{UCAPAN TERIMA KASIH}

Kami menyampaikan terima kasih kepada Kementerian Riset, Teknologi dan Pendidikan Tinggi melalui LPPM Universitas Pattimura yang mendanai penelitian ini pada Skim Penelitian Produk Terapan tahun 2017 dan dilanjutkan pada Skim Penelitian Strategis Nasional-Institusi tahun 2018 dengan judul "Produksi Klon-Klon Ubi Jalar Harapan Asal Provinsi Maluku Berdasarkan Potensi Hasil, Adaptabilitas dan Stabilitas pada Lingkungan Lokal".

\section{DAFTAR PUSTAKA}

Ahmed, F., M.Y. Rafii, M.R. Ismail, A.S. Juraimi, H.A. Rahim, R. Asfaliza, and M.A. Latif. 2013. Waterlogging tolerance of crops: breeding, mechanism of tolerance, molecular approaches, and future prospects. BioMed Research International ArticleID 963525, 10 pages http://dx.doi.org/10.1155/2013/963525.

Aldana, F., P.N. Gracia, and G. Fischer. 2014. Effect of waterlogging stress on the growth, development and symptomatology of cape gooseberry (Physalis peruviana L.) plants. Revista de la Academia Colombiana de Ciencias Exactas, Fisicas y Naturales 38: 393-400.

(BSN) Badan Standarisasi Nasional. 1998. Ubi Jalar. Standar Nasional Indonesia Nomor 01.4493.1998.

Badu, M., P. Ashok, T.S.K.K.K. Patro, and K. Sasikala. 2017. Studies on genetic variability, heritability and genetic advance for growth, yield and quality parameter among orange flesh sweet potato [Ipomoea batatas (L.) Lam] genotypes. International Journal of Current Microbiology and Applied Science 6: 1894-1903. https://doi.org/10.20546/ijcmas.2017.609.233

Bailey-Serres, J., S.C. Lee, and E. Brinton. 2012. Waterproofing crops: effective flooding survival strategies. Plant Physiology 160: 1698-1709. https://doi.org/10.1104/pp.112.208173

Chen, X., R. Pierik, A.J.M. Peeters, H. Poorter, E.J.W. Visser, H. Huber, H. de Kroon, and L.A.C.J. Voesenek. 2010. Endogenous abscisic acid as a key switch for natural variation in flooding-induced shoot elongation. Plant Physiology 154: 969-977. doi: 10.1104/pp.110.162792

Chen, X., M. Kou, Z. Tang, A. Zhang, H. Li, and M. Wei. 2017. Responses of root physiological characteristics and yield of sweet potato to humic acid urea fertilizer. PLoS One 12: 1-11. https://doi.org/10.1371/journal.pone.0189715

Colmer, T.D., and L.A.C.J. Voesenek. 2009. Flooding tolerance: suites of plant traits in variable environments. Functional Plant Biology 36: 665681.

Dawood, T., I. Rieu, M. Woltres-Arts, E.B. Derksen, C. Mariani, and E.J. Visser. 2013. Rapid floodinginduced adventitious root development from performed primordia in Solanum dulcamara. $A o B$ Plants 6:1-13. doi:10.1093/aobpla/plt058.

Ezin, V., R. De La Pena, and A. Ahanchede. 2010. Flooding tolerance of tomato genotypes during vegetative and reproductive stages. Brazilian Society of Plant Physiology 22: 131-142. http://dx.doi.org/10.1590/S167704202010000200007

Hetharie, H. S.H.T. Raharjo, G.H. Augustyn, dan M. Pesireron. 2017. Akurasi karakterisasi tingkat in situ tanaman ubi jalar pada Kecamatan Inomosol dan Huamual Muka di Kabupaten Seram Bagian Barat. Jurnal Budidaya Pertanian 13: 103-110.

Hossain, M.A., and S.N. Uddin. 2011. Mechanisms of waterlogging tolerance in wheat: Morphological and metabolic adaptations under hypoxia or anoxia. Australian Journal of Crop Science 5: 1094-1101.

Kende, H., E. van der Knaap, and Cho Hyung-Taeg. 1998. Deepwater rice: a model plant to study stem elongation. Plant Physiology 118: 1105-1110. https://doi.org/10.1104/pp.118.4.1105 
Malik, A.I., T.I. Ailewe, and W. Erskine. 2015. Tolerance of three grain legume species to transient waterlogging. $A o B$ Plants 7: 1-11. doi: 10.1093/aobpla/plv040.

Minantyorini, dan M. Setyowati. 2016. Potensi hasil aksesi plasma nutfah ubi jalar di dataran tinggi. Buletin Plasma Nutfah. 22: 31-40. DOI http://dx.doi.org/10.24831/jai.v45i2.13077

Putri, F.D., Sobir, M. Syukur, dan A. Maharijaya. 2017. Pengembangan kriteria seleksi untuk perakitan terung (Solanum melongena L.) berdaya hasil tinggi. Jurnal Agronomi Indonesia 45: 182-187.

Ozias-Akins, P. and R.L. Jarret. 1994. Nuclear DNA content and ploidy levels in the genus Ipomoea. Journal of American Society for Horticultural Science 119: 110-115.

Pinaria, A., A. Baihaki, R. Setiamihardja, dan A.A. Daradjat. 1995. Variabilitas genetik dan heritabilitas karakter-karakter biomassa 53 genotipe kedelai. Zuriat 6: 80-87.

Qosim, W.A., M. Rachmadi, J.S. Hamdani, dan I. Nuri. 2013. Penampilan fenotipik, variabilitas, dan heritabilitas 32 genotipe cabe merah berdaya hasil tinggi. Jurnal Agronomi Indonesia 41: 140-146. http://dx.doi.org/10.24831/jai.v41i2.7519

Rahajeng, W. and S.A. Rahayuningsih. 2017. Agronomic performance, variance component, and diversity of sixty-two sweet potato accessions. Biodiversity 18: 95-100. DOI: 10.13057/biodiv/d180114

Raharjo, S.H.T., H. Hetharie, G.H. Augustyn, dan M. Pesireron. 2014. Keragaman Ubi Kayu dan Ubi
Jalar di Seram Bagian Barat dan Peluang Pemanfaatannya Untuk Ketahanan Pangan dan Industri. hal. 73-102. Dalam W. Girsang dan R. M. Osok (Eds.). Percepatan Pembangunan Ekonomi Berbasis Hasil Kajian Pertanian dan Perikanan di Provinsi Maluku. Pensil Komunika, Yogyakarta.

Scott, H.D., J. DeAngulo, M.B. Daniels, and L.S.Wood. 1989. Flood duration effects on soybean growth and yield. Agronomy Journal 81: 631-636.

Striker, G.G. 2012. Flooding Stress on Plant: Anatomical, Morphological and Physiological Responses. p.128. In John Mworia (Ed.). Botany. InTech.

Syukur, M., S. Sujiprihati, R. Yunianti, dan K. Nida. 2010. Pendugaan komponen ragam, heritabilitas dan korelasi untuk menentukan kriteria seleksi cabai (Capsicum annuum 1.) populasi F5. Jurnal Hortikultura Indonesia 1: 74-80.

Villordon, A.Q., D.R. La Bonte, and N. Firon. 2009. Characterization of adventitious root development in sweet potato. HortScience. 44: 651-655.

Wahyuni, T.S., St.A. Rahayuningsih, dan K.H. Hartojo. 2004. Pendugaan parameter genetik dan hubungan beberapa karakter kuantitatif dengan hasil beberapa klon harapan ubi jalar. Penelitian Pertanian Tanaman Pangan. 23: 109-116

Wilson, L.A. 1982. Tuberization in sweet potato (Ipomoea batatas (L.) Lam.). p. 79-94. In: Villareal, R.L. and T.D. Griggs (Eds). Sweet Potato Proceeding of the First International Symposium, Tainan, Taiwan, AVRDC. 